BRANKA REGOVIĆ

bregovic@h-r-z.hr

MARIJA ZUPČIĆ*

mzupcic@h-r-z.hr

MARTA BUDICIN*

mbudicin@h-r-z.hr

* Hrvatski restauratorski zavod
Primljeno: 15. 01. 2019.

Prihvaćeno: 09. 05. 2019.

DOI: $10.21857 / \mathrm{mjrl} 3$ uxr09

\title{
TEKSTILNI PREDMETI IZ GRADSKOG MUZEJA VARAŽDIN RESTAURIRANI NA ODJELU ZA TEKSTIL, PAPIR I KOŽU HRVATSKOG RESTAURATORSKOG ZAVODA
}

U ovom radu autorice predstavljaju konzervatorsko-restauratorske radove te opis građanskog i liturgijskog ruha Gradskog muzeja Varaždin.

\section{UVOD}

Stalni postav Kulturnopovijesnog odjela Gradskog muzeja Varaždin u 2014. godini proširen je novom muzeološkom cjelinom Kultura odijevanja od 18. do sredine 20. stoljeća čiju je realizaciju, između ostalog, omogućila i višegodišnja uspješna suradnja Odjela za tekstil, papir i kožu Hrvatskog restauratorskog zavoda i Gradskog muzeja Varaždin započeta 2007. godine konzervatorsko-restauratorskim radovima na obnovi budućih izložaka, uglavnom ženskih odjevnih predmeta i pripadajućih modnih dodataka. 
Izrađeni u brojnim domaćim i stranim radionicama za varaždinske građanke i plemkinje, ovi predmeti oslikavaju povijesne i društvene prilike s kraja 19. i početka 20. stoljeća i svjedoče činjenici da je Varaždin oduvijek bio izraziti kulturni, umjetnički i obrtnički centar na našim prostorima. Kulturu odijevanja navedenog razdoblja karakterizira raznorodnost pristupa pojmu ženstvenosti čemu uvelike doprinose progresivna tehnička otkrića i industrijalizacija.

\section{ŽENSKI ODJEVNI PREDMETI I MODNI DODACI IZ DRUGE POLOVICE 18. DO DRUGE POLOVICE 19. STOLJEĆA}

Od predmeta restauriranih na Odjelu za tekstil, papir i kožu najstarija je lepeza inv. br. GMV KPO 1294 datirana u razdoblje od 1787. godine do kraja 18. stoljeća. Izrađena je od svilene tkanine s apliciranim titrankama i vezom, a oslikana u tehnici tempere prikazom poznate opere „L'arbore de Diana“ ili „Dijanino drvo“ čiji je autor Vicente Martin y Soler, a autor libreta Lorenzo da Ponte. Premijera ove opere održana je u listopadu 1787. godine i obilježila je vjenčanje nećakinje Josipa II, nadvojvotkinje Marije Terezije sa saksonskim kraljem Antonom. Prikazana scena odnosi se na izvedbu ove, u to vrijeme veoma popularne opere i pokazuje božicu Dijanu koja gađa u štit obavijen girlandama od ruža kojeg drži Endimion.

Lepeza je zatečena u izrazito lošem stanju očuvanosti, krhke i djelomično odljepljene glavne tkanine. Osim onečišćenja prašinom zatečene su mrlje i brojna mehanička oštećenja koja su narušavala konstrukcijsku stabilnost predmeta. Uz rubove su zatečene veće i manje pukotine, oslik je mjestimice nedostajao. Uz nedostatak četiri rebara od slonovače, preostala su rebra bila onečišćena i diskolorirana.

Konzervatorsko-restauratorski radovi na lepezi započeli su restauratorskim istraživanjima i probnim čišćenjem sastavnih dijelova. Sloj površinske nečistoće uklonjen je mehanički. U svrhu umetanja potpora oštećenjima lepezu je bilo potrebno djelomično odvojiti, a za potrebe konstrukcijske stabilnosti rekonstruirana su nedostajuća rebra i svilena tkanina. 


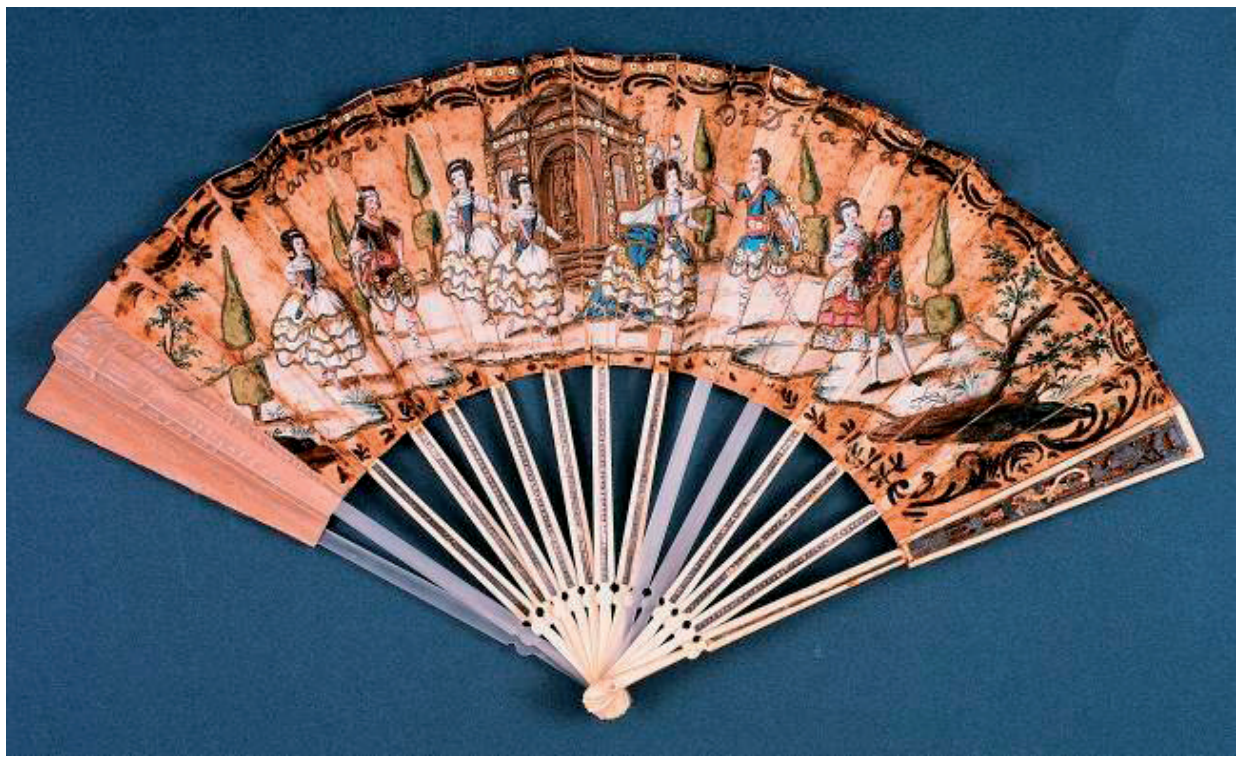

Slika 1. Lepeza GMV KPO 1294, kraj 18. st., stanje nakon radova, (fototeka HRZ-a, snimio Jovan Kliska)

Uz lepeze kao obavezni modni dodatak ženskih odjevnih kombinacija u 18. i 19. stoljeću značajno mjesto zauzimaju i suncobrani. Ženski suncobran inv. br. GMV 44463 datiran je u kraj 18. i početak 19. stoljeća, a izrađen je od svilenih tkanina, ukrasnih resa i drvenog štapa s drškom te vrhom od slonovače. Ovakav tip suncobrana javlja se u Europi u vrijeme klasicizma, podsjeća na pagodu i pripada tipu kineskog suncobrana posebno cijenjenog u empire razdoblju. Glavna i podstavna tkanina bile su isušene i krte, posebno na središnjem dijelu s velikim mehaničkim i fotokemijskim oštećenjima u vidu izrazite tamne mrlje. Ukrasne su rese također bile isušene, zamršene i mjestimično potrgane, a drška diskolorirana s nedostajućim donjim dijelom. Čelična je konstrukcija bila deformirana, a vrhovi žica oštro odrezani što je uzrokovalo oštećenja na svilenoj podstavnoj tkanini. 


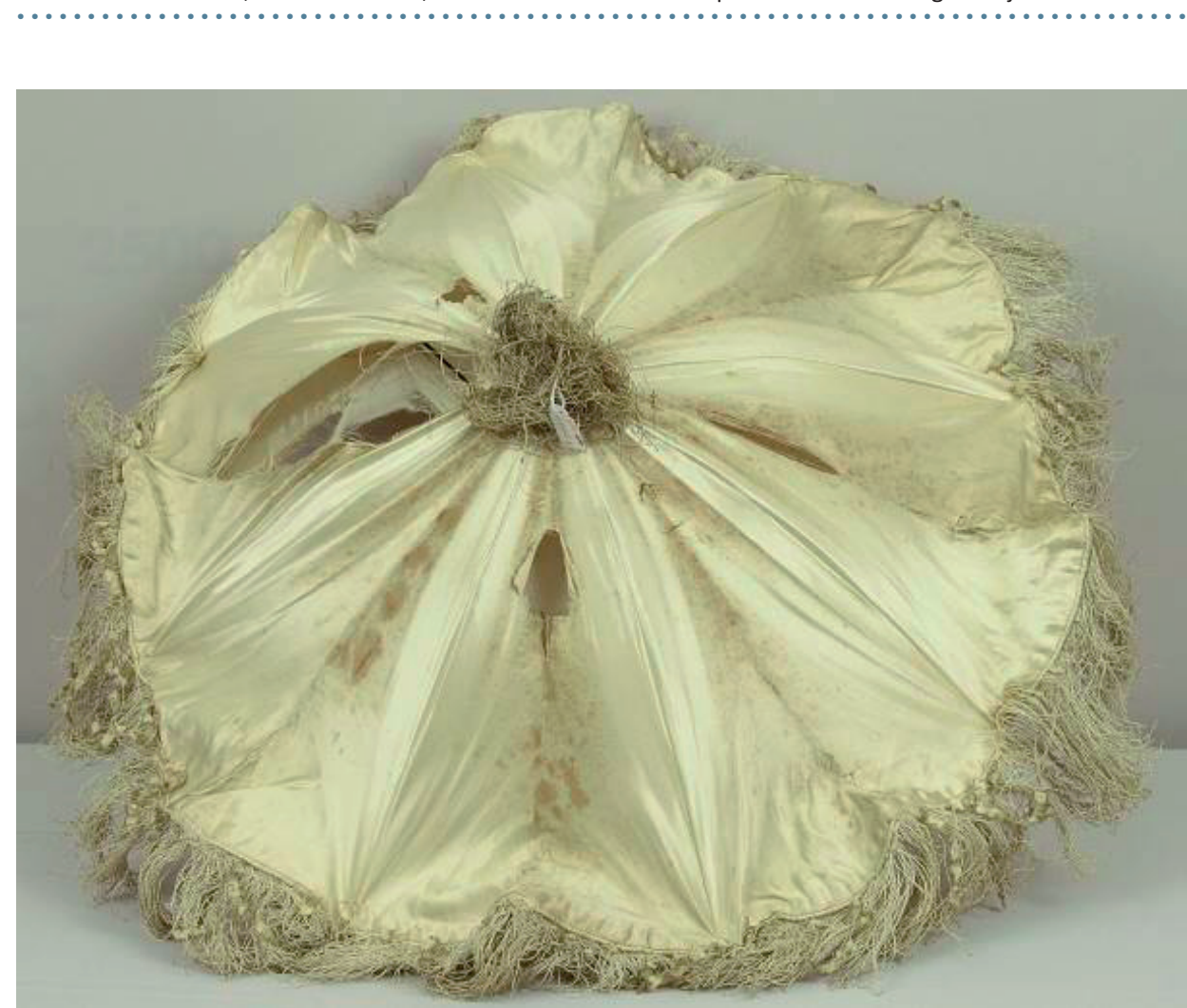

Slika 2. Ženski suncobran GMV-44463, kraj 18.- početak 19. st., stanje prije radova, (fototeka HRZ-a, snimila Natalija Vasić)

Cjelovitim konzervatorsko-restauratorskim radovima prethodila su istraživanja i detaljno fotodokumentiranje, a potom je izvedeno mokro čišćenje tekstilnih dijelova, cjelovita potpora te zatvaranje oštećenja konzervatorskim bodom. Rekonstruiran je nedostajući dio vrha i drška suncobrana te je izravnata iskrivljena konstrukcija, a potom je tkanina vraćena na očišćenu i stabiliziranu konstrukciju.

Suncobran inv. br. GMV KPO 1801 potječe iz prve polovice 19. stoljeća kada u europsku modu ulaze suncobrani manjih dimenzija. Pripada tipu pregibnog, sklopivog i lako prenosivog suncobrana koji se javlja već oko 1815. godine. Izrađen je od svilenih tkanina i drvenog štapa sa žicama od bambusa, dok su vrh i drška od slonovače. Svilene tkanine suncobrana bile su onečišćene prašinom, a na pregibima prekrivene većim pukotinama. Nakon uklanjanja tkanina s konstrukcije, mokrog čišćenja, sušenja i ravnanja, oštećenja su potpuno podložena i zatvorena konzervatorskim bodom te vraćena na očišćenu i stabiliziranu konstrukciju. 
Krajem 18. i u prvim desetljećima 19. stoljeća u odjevnim trendovima dolazi do zaokreta u odnosu na raskošne barokne i rokoko modele te se koriste laganiji i prozračniji materijali i jednostavni krojevi koji se referiraju na modu grčkog i rimskog doba.

Haljina inv. br. GMV KPO 2888 otkupljena je u Bjelovaru od Viktorije Karner, a izrađena početkom 19. stoljeća, moguće u razdoblju od 1805 . do 1810 . godine i stilski pripada razdoblju empira (1800. - 1815.). Glavna joj je tkanina svilena s okomitim prugama oker boje i boje slonovače te viticama s plavim lišćem, zlatnim cvjetićima i zlaćanim pupoljcima. U gornjem se dijelu sastoji od lanenog prsluka i pričvršćenih dugih svilenih rukava inv. br. GMV KPO 2892. Haljine ovog perioda karakterizira visoki struk do ispod grudi, duboki okrugli vratni izrez, široki i kratki rukavi te ravan kroj do gležnjeva. Specifičnost haljine inv. br. GMV KPO 2888 je u tome što joj glavna tkanina potječe iz druge polovice 18. stoljeća, odn. razdoblja rokokoa koji preferira raskošne i ljupke materijale kao što su svila, taft i damast te svijetle, pastelne boje i cvjetne motive na svijetloj podlozi. Navedena tkanina starijeg stilskog razdoblja u ovom je primjeru iskorištena u izradi haljine mlađeg stilskog razdoblja i primjer je vrlo uspješne koegzistencije ovih stilski posve različitih izričaja.

Tijekom restauratorskih istraživanja na haljini, utvrđen je niz povijesnih intervencija na konstrukciji kroja u vidu širenja i sužavanja modela. Nakon konzervatorsko-restauratorskih radova izrađena je i prilagođena pripadajuća izložbena lutka za izlaganje. ${ }^{1}$

Oblikovanje izložbene lutke izvedeno je prema uputama u: Lara FLECKER, A Practical Guide to Costume Mounting, Elsevier, Butterworth-Heinemann, Oxford, 2007. 


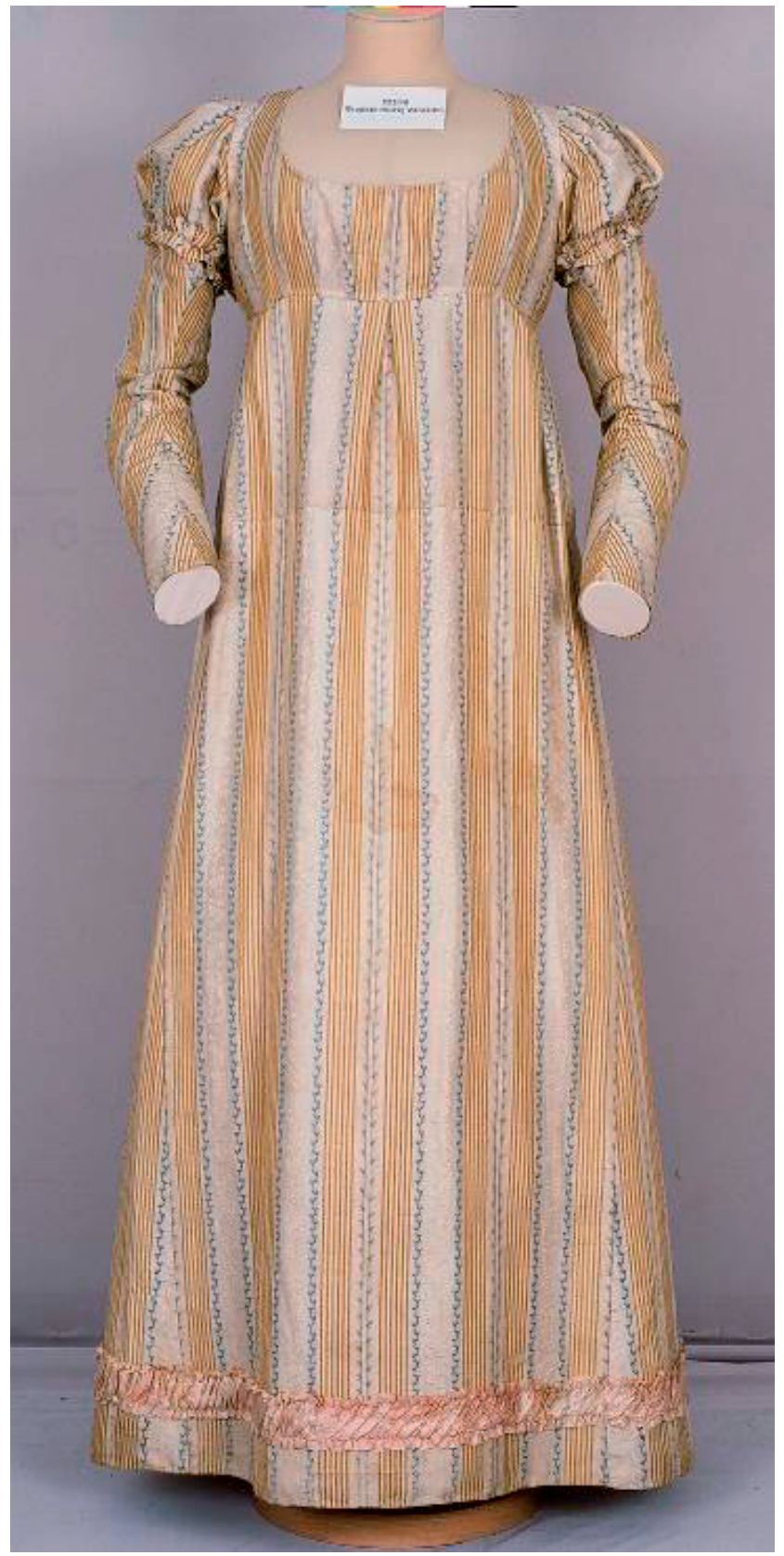

Slika 3. Haljina GMV-KPO 2888, početak 19. st., na lutki za stalni postav, stanje nakon radova (fototeka HRZ-a, snimila Natalija Vasić) 
Dvadesetih godina 19. stoljeća krojevi ženskih haljina i rukava šire se prema rubovima. Suknjama se povećavao volumen uz nekoliko slojeva podsuknji, a četrdesetih i pedesetih godina afirmira se upotreba krinoline.

\section{ŽENSKI ODJEVNI PREDMETI I MODNI DODACI IZ DRUGE POLOVICE 19. DO POČETKA 20. STOLJEĆA}

U drugu polovicu 19. stoljeća, točnije 1860. i 1870. godinu datirana su tri ženska odjevna predmeta; kaputić inv. br. GMV KPO 2890, kaputić inv. br. GMV KPO 2891 i pripadajuća suknja inv. br. GMV KPO 2889.

Ženski kaputić inv. br. GMV KPO 2890 izrađen je od zelene svilene tkanine i doseže do struka. Zatvara se s prednje strane francuskim kopčama, a ukrašen je nazubljenim trakama i plišanim vrpcama na ramenom dijelu i rukavima koji se pri dnu šire. Izvedeni su cjeloviti konzervatorsko-restauratorski radovi te je izrađena rekonstrukcija pripadajuće suknje prema modelu suknji iz 1860. godine², a uz nju izložbena lutka sa žičanom krinolinom kako bi ovaj predmet mogao u punom sjaju biti izložen u budućem stalnom postavu.

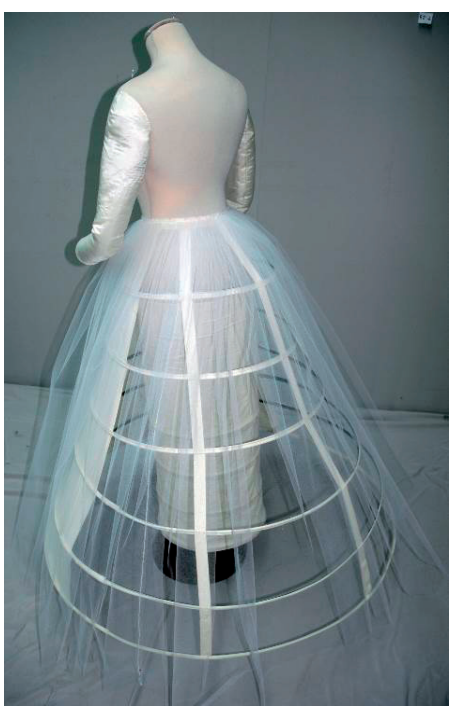

Slika 4. Izložbena lutka s krinolinom tijekom radova (dokumentacija HRZ-a, snimila Branka Regović)

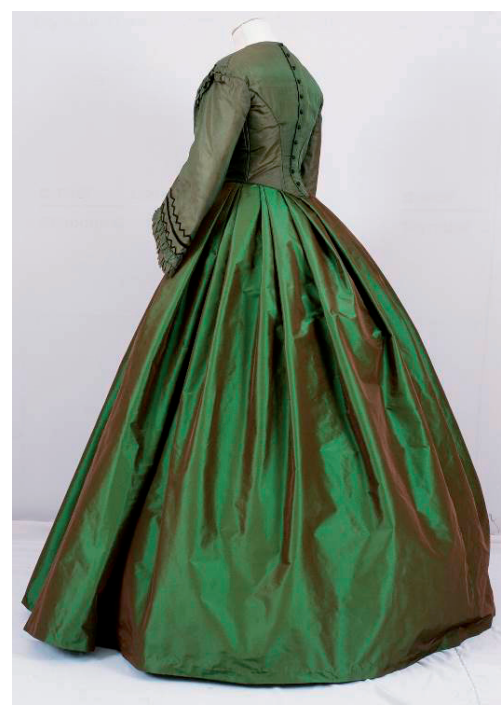

Slika 5. Ženski kaputić GMV-KPO 2890, druga polovica 19. st., stanje nakon radova, (fototeka HRZ-a, snimila Natalija Vasić)

2 Rekonstrukcija suknje izvedena je prema kroju iz: Janet ARNOLD, Patterns of Fashion 2, Englishwomen's dresses and their construction c. 1860-1940, Macmillan, London, 1977., 28, 29. 
Kaputić inv. br. GMV KPO 2891 i pripadajuća suknja inv. br. GMV KPO 2889 datirani su u 1870. godinu, a izrađeni od više vrsta svilenih tkanina i vrpci. Tijekom restauratorskih istraživanja utvrđeni su tragovi krojačkih prepravaka u vidu širenja u predjelu struka. Za ovaj komplet je također dorađena izložbena lutka s krinolinom.

Krajem sedamdesetih godina 19. stoljeća u modu ulazi uži kroj ženskih haljina s posebno naglašenim stražnjim djelom. Umetnutim jastučićima, konstrukcijom od ratana ili žice dobiva se tzv. „pariška stražnjica“.

Ogrtač inv. br. GMV KPO 1786 tipičan je primjer odjevnog predmeta navedenog razdoblja naglašenog leđnog dijela u predjelu ispod struka, bogato ukrašen mašnama i čipkom. Izrađen je od vunenih i svilenih tkanina te bogato ukrašen aplikacijama vezenim perlicama na tilu. Rubni ukrasi izrađeni su od više vrsta svilenih čipki, traka i mašni. Detaljnim pregledom predmeta utvrđena su velika oštećenja glavne vunene tkanine. Djelovanje moljaca uzrokovalo je velika strukturna oštećenja u vidu velikih rupa u tkanju. Izrazita strukturna oštećenja zatečena su i na podstavnoj svilenoj tkanini za koju se pretpostavlja kako je u fazi dorade bila tretirana nepoznatim kemijskim sredstvom u svrhu postizanja efekta sjaja ili mekoće, što je karakteristično za onodobnu proizvodnju svilenih tkanina. Zbog visokog stupnja degradacije tkanine, nakon uklanjanja zatečenih intervencija raspadnuta svilena podstava konzervirana je u sendvič od tanje svilene tkanine i tila. Oštećenja na glavnoj vunenoj tkanini podložena su i zatvorena, a vezene aplikacije konzervirane restauratorskim tilom. Za ogrtač je dorađena izložbena lutka po mjeri uz dodatak umetka za „parišku stražnjicu“ te je rekonstruirana suknja. 


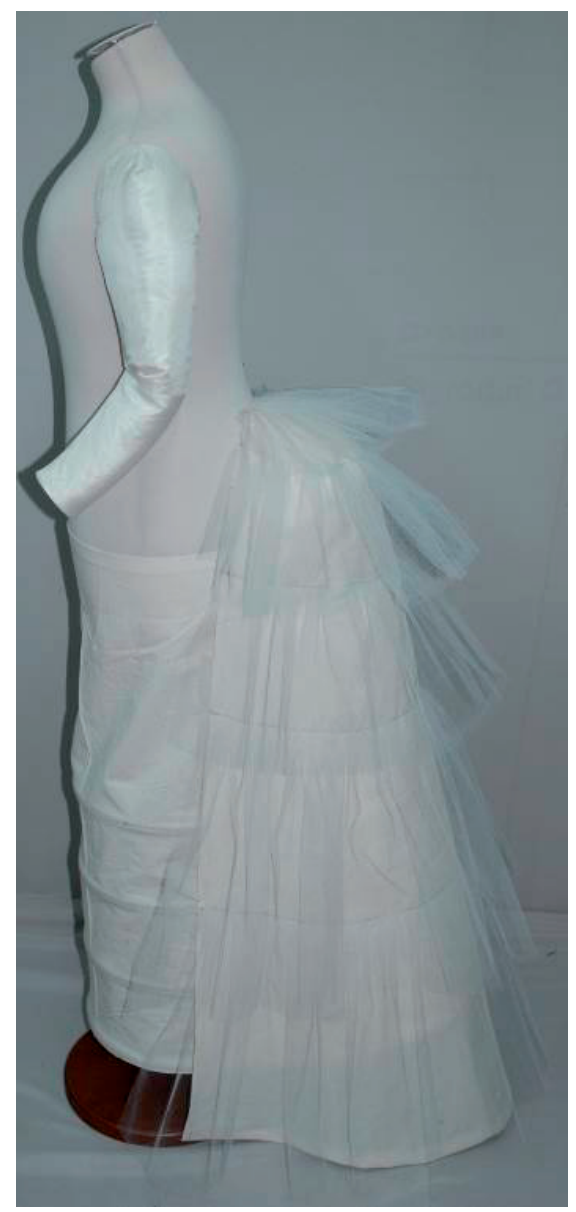

Slika 6. Izložbena lutka s umetkom za „parišku stražnjicu“ tijekom radova (dokumentacija HRZ-a, snimila Branka Regović)

Upotreba lepeza postala je općeprihvaćena i obavezna pratnja odijevanju kroz čitavo to razdoblje. U drugoj polovici 19. stoljeća vrlo je popularna i kineska, odnosno mandarinska kultura.

Uz porculan i keramiku uvozile su se i mandarinske živopisne lepeze s folklornim elementima, prikazima krajolika, cvijeća i vrtova, palača, a za njih su karakteristične kombinirane tehnike izrade. 


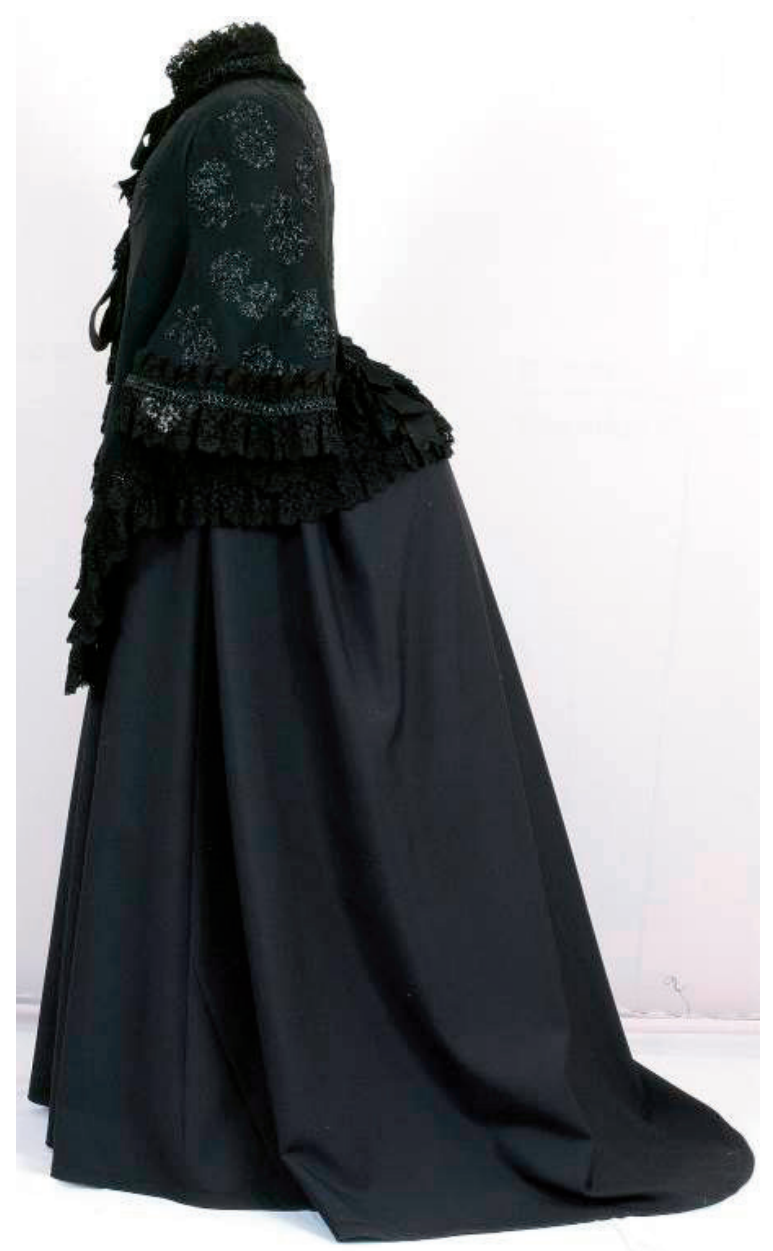

Slika 7. Ženski ogrtač GMV-KPO 1786 na izložbenoj lutki, druga polovica 19. st., stanje nakon radova,(fototeka HRZ-a, snimila Natalija Vasić)

Lepeza GMV-KPO 1288 zanimljiv je primjer mandarinske lepeze s rebrima od slonovače koja je izrezbarena tehnikom „na proboj“. Na obje strane temperom su oslikane scene iz svakodnevnog života, a dodatno su ukrašene različitim dekorativnim uzorcima. Lica prikazanih figura izrađena su od tankog ovalnog i oslikanog lista slonovače, a odjeća je izrezana od svilene tkanine i aplicirana ljepilom te dodatno oslikana. Lepeza je zatečena u vrlo lošem stanju očuvano- 
sti, onečišćena i s mehaničkim oštećenjima na svim pregibima i uz rubove gdje su zatečene i uzdužne pukotine. Dodatna oštećenja na osliku nastala su i zbog naknadnih intervencija zatvaranja pukotina različitim i neprimjerenim ljepljivim trakama i papirima. Krajnje desno rebro bilo je slomljeno i nedostajao je gornji dio.

Nakon utvrđivanja vrste ljepila, pristupilo se uklanjanju zatečenih ljepljivih traka i tragova tutkala nakon čega je utvrđen je visok stupanj oštećenosti lepeze. Osim velikih pukotina na papirnatim nosiocima donji i gornji rubovi bili su djelomično odlijepljeni. Čitava je nestabilna konstrukcija konzervirana nanošenjem Tylose između odvojenih slojeva papira, a nedostajući dio krajnjeg rebra izrađen je od umjetne slonovače (poliester) i pričvršćen na ostatak oštećenog rebra. Za potpuno stabiliziranje lepeze umetnut je gornji oštećeni dio lepeze u sendvič od konzervatorskog tila. Šivanje je izvedeno svilenom niti između rebara lepeze kako bi se dobili funkcionalni pregibi te mogućnost sklapanja lepeze.

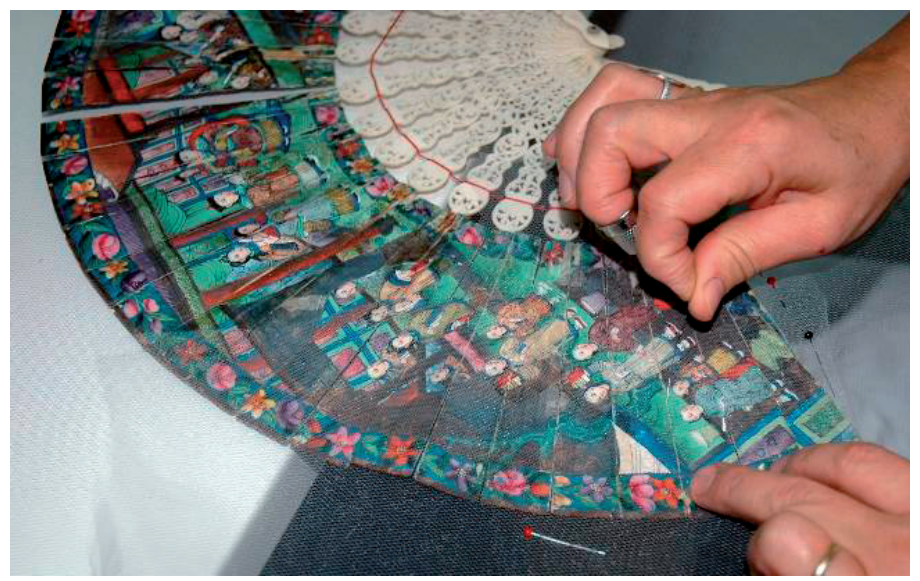

Slika 8. Lepeza GMV-KPO 1288, druga polovica 19. st., tijekom radova, (dokumentacija HRZ-a, snimila Branka Regović)

Za potrebe izlaganja u stalnom postavu izrađeno je postolje od pleksiglasa koje je desetak centimetara uzdignuto od površine kako bi se na podlogu u izložbenu vitrinu moglo postaviti ogledalo. U ogledalu će se moći vidjeti druga strana lepeze.

Još jedan zanimljivi primjer ženskog modnog dodatka je kapa za žalovanje inv. br. GMV KPO 3021. Ovaj oblik pokrivala za glavu javlja se u drugoj polovici 19. stoljeća u vrijeme historicizma, a vezuje se uz odjeću za žalovanje koju je u 
BRANKA REGOVIĆ, MARIJA ZUPČIĆ, MARTA BUDICIN: Tekstilni predmeti iz Gradskog muzeja Varaždin ...

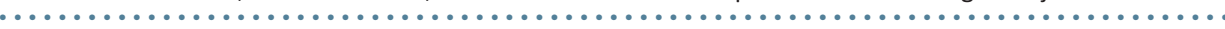

modu uvela engleska kraljica Viktorija. Izrađena je od crne svilene tkanine, gornji joj je dio oblikovan kao toka koja na čeonom dijelu ima ukrase od pliša u obliku latica sa staklenim perlicama uz dodatak više vrsta čipke. Između gornje i donje tkanine punjena je pamučnom vatom. Uokolo gornjeg dijela kape pričvršćen je donji dio lepezastog oblika koji prekriva ramena.

Uz mehanička oštećenja od djelovanja insekata po cijeloj površini glavne tkanine zatečeno je površinsko i dubinsko onečišćenje prašinom. Kapa je dodatno bila deformirana pregibima po cijeloj površini.

Izvedeni su cjeloviti konzervatorsko-restauratorski radovi te detaljna i pažljiva konzervacija ukrasa na čeonom dijelu kojima je vraćen prvobitni oblik i sjaj ovom iznimnom predmetu.

Krajem 19. i početkom 20. stoljeća u vrijeme secesije, modni se izričaj okreće udobnosti i prozračnosti, s izrazitom predilekcijom za lagane i fine materijale, čipku, cvjetne motive te ležernije kraće krojeve. U ovaj zanimljiv period koji odbacuje modne autoritete i tradiciju spadaju dnevna haljina inv. br. GMV 44520 i ženska bluza inv. br. GMV 44462.

Dnevna haljina izrađena je kombinacijom svijetloplave pamučne i svilene tkanine, a ukrašena apliciranom čipkom. Na konzervatorsko-restauratorske radove dopremljena je površinski onečišćena s vidljivim mrljama različitog porijekla. Nedostajala je podstava donjeg dijela haljine, a sam kroj je pretrpio nekoliko povijesnih intervencija u vidu dodavanja nove tkanine u predjelu dekoltea. Odstranjivanjem neprimjerenih povijesnih prepravaka, mokrim čišćenjem, ojačavanjem šavova na aplikacijama, ravnanjem i oblikovanjem na izložbenoj lutki dnevnoj je haljini vraćen prvobitni izgled kao i secesijskoj crnoj ženskoj bluzi s početka 20. stoljeća izrađenoj od finih svilenih, pamučnih tkanina i lepršave čipke.

Haljina inv. br. GMV KPO 74401 izrađena je u New Yorku u razdoblju od 1900. do 1905. u radionici Rock \& Torpey. Stilski i kronološki pripada edvardijanskom dobu (1901.-1910.) koje u pogledu ženske odjeće karakterizira „S“ silueta i upotreba korzeta, dugačke, zvonolike haljine uskog struka, visokih ovratnika kod dnevnih haljina, odn. dubokih dekoltea te široki rukavi i bogata upotreba čipke kod večernjih haljina. Haljina se sastoji od suknje i bluze s visokim ovratnikom i dugim rukavima nabranim i širim u gornjem dijelu, a izrađena je u više slojeva svilene tkanine i čipke. Suknja je izrađena od smeđe svilene tkanine s našivenom većom crnom čipkom. Po uzoru na onodobne krojeve, stražnji dio suknje je dulji od prednjeg te je nabran u struku. Ispod svilene tkanine našivena je organdi tkanina gusto nabrana na stražnjem, srednjem šavu. Zadnji sloj suknje izrađen je od taft tkanine s bogato nabranim donjim volanom. Na desnoj strani bočnog šava taft tkanine izrađen je džep. Bluza je u potpunosti bila izrađena od svile, no 
u jednom je trenutku prekrojena i dio originalne svilene tkanine zamijenjen je poliesterskom tkaninom, dok je suknja sužena u struku. Konzerviranje i restauriranje haljine je bilo opsežno i zahtjevno. Prekrojena suknja mogla se vratiti u prvotno stanje, dok to na bluzi nije bilo moguće zbog strojno našivenih dijelova. Najzahtjevniji radovi odnosili su se na zatvaranje oštećenja svih slojeva haljine i čipke. Za potrebe izlaganja haljine u stalnom postavu muzeja izrađena je izložbena lutka.

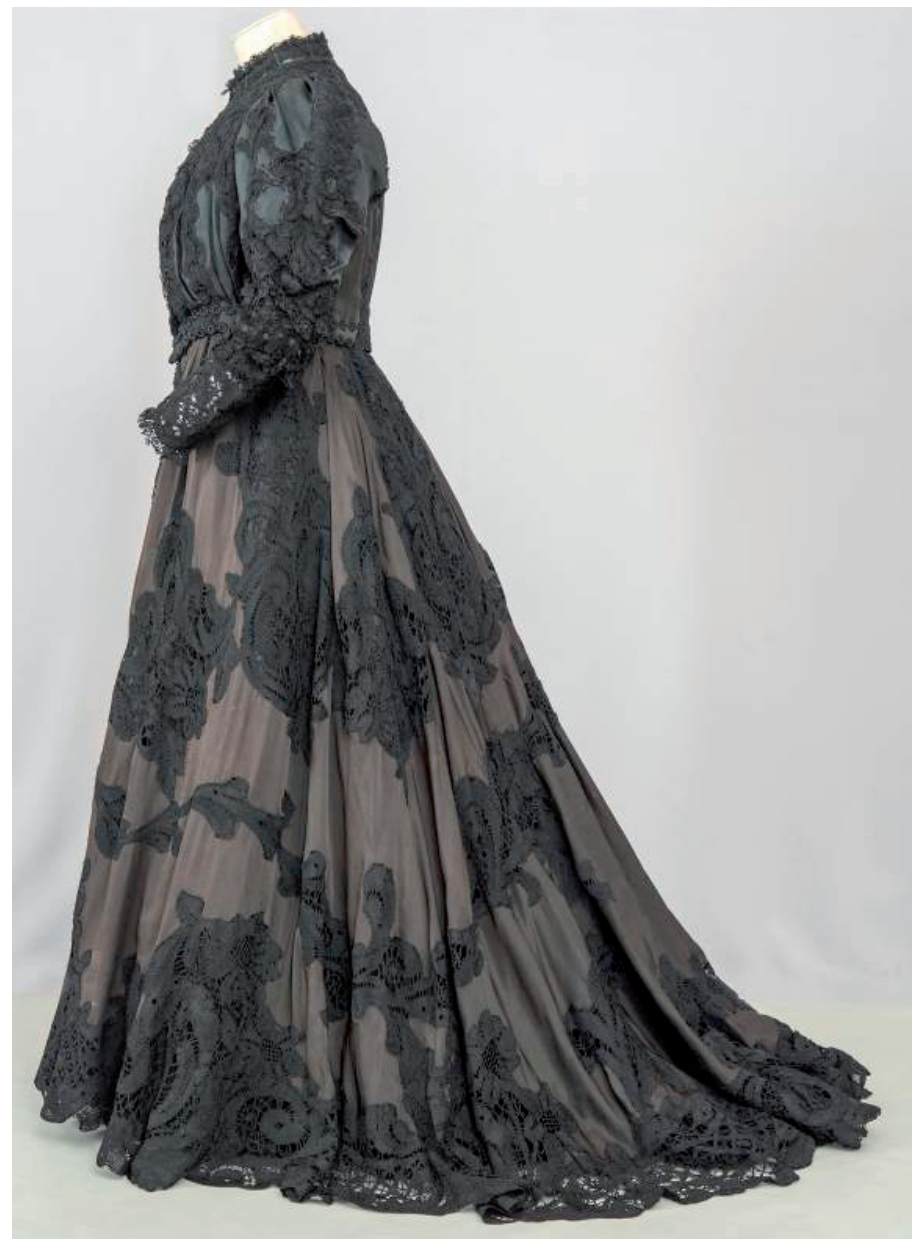

Slika 9. Haljina GMV KPO 74401, 1900.-1905. g., stanje nakon radova, (fototeka HRZ-a, snimio Jovan Kliska) 
BRANKA REGOVIĆ, MARIJA ZUPČIĆ, MARTA BUDICIN: Tekstilni predmeti iz Gradskog muzeja Varaždin ...

\section{LITURGIJSKO RUHO I OPREMA IZ DRUGE POLOVICE 15. DO DRUGE POLOVICE 19. STOLJEĆA}

U 2012. godini započeti su konzervatorsko-restauratorski radovi na liturgijskim predmetima za potrebe izložbe Vjera, ufanje, ljubav, koja je održana u 2013., a koji su namijenjeni i budućoj Sakralnoj zbirci.

Odjeća za kip Marije s Isusom inv. br. GMV 59578/1 i GMV 59578/2 iz 19. stoljeća jednostavne je konstrukcije u obliku plašta izrađenog od svilenih tkanina obrubljenih i ukrašenih metalnom čipkom. Na svjetlijoj svilenoj podlozi se okomito nižu sakralni motivi poput križa, Davidove zvijezde, hostije i dva zavjetna kamena s deset Božjih zapovijedi te dodatno stilizirani biljni i geometrijski motivi. Tkanina ima grešku u tkanju koja se može uočiti na brojevima Božjih zapovjedi. $\mathrm{Na}$ navedenim su predmetima izvedeni cjeloviti konzervatorsko-restauratorski radovi.

Velum inv. br. GMV KPO 2398 iz 17. stoljeća izrađen je od bordo svilenog tafta s ručno rađenom metalnom čipkom i našivenim biljnim motivima izrađenim od svilenog zelenog baršuna i metalnih niti. Podstavna tkanina je novija te je izrađena od pamučnog platna. U središnjem dijelu veluma izvezen je Veronikin rubac, a površina veluma je dodatno ukrašena lišćem vinove loze, heraldičkim ljiljanom te drugim stiliziranim lišćem i cvijećem. Nakon pripremnih radnji na velumu, metalna čipka je konzervirana našivanjem tkanine od tila, dok su oštećenja glavne i podstavne tkanine zatvorena postupkom djelomičnog podlaganja i šivanja. Predmeti su završno vlaženi i izravnati te pravilno pohranjeni.

Pala inv. br. GMV KPO 1345 rad je nepoznatog autora, a potječe iz 19. stoljeća. Izrađena je od svilene tkanine s vezom od svilenih i metalnih niti, ukrašena metalnim titrankama i aplikacijama te ima papirnu podlogu i svilenu podstavu. Vezeni motivi izrađeni su metalnim i svilenim nitima žute, bordo, crne, ružičaste i beige boje. Rubovi pale su prekriveni prišivenom debljom metalnom niti, a na samom je rubu valovita metalna lamela. Između vezenih prikaza našivene su metalne titranke i metalne aplikacije različitih oblika. U unutrašnjosti pale pronađeno je nekoliko slojeva papira spojenih koncem. Na papirima je odštampan Časoslov na latinskom jeziku. Tekst je ukrašen stiliziranim biljnim, cvjetnim i religijskim motivima i grbovima. Na prvom papiru koji je služio kao podloga za vezenje zatečen je nečitljiv ručno ispisan tekst.

Površina prednje strane pale u središtu je ukrašena vezenim motivom Jaganjca Božjeg s pobjedničkom zastavom i procesionalnim križem, a ostatak površine ispunjen je prikazima četiri poveća cvijeta sa stabljikama i dva lista. Cvjetovi su troslojni, izvezeni bordo i ružičastom svilenom pređom te metalnim nitima. 
Stanje pale je dokumentirano, izrađene su laboratorijske i strukturne analize te suho čišćenje, učvršćivanje aplikacija i lamela te napuknutih dijelova papira i tkanine. Glavna i podstavna tkanina su podložene, a oštećenja zatvorena šivanjem.

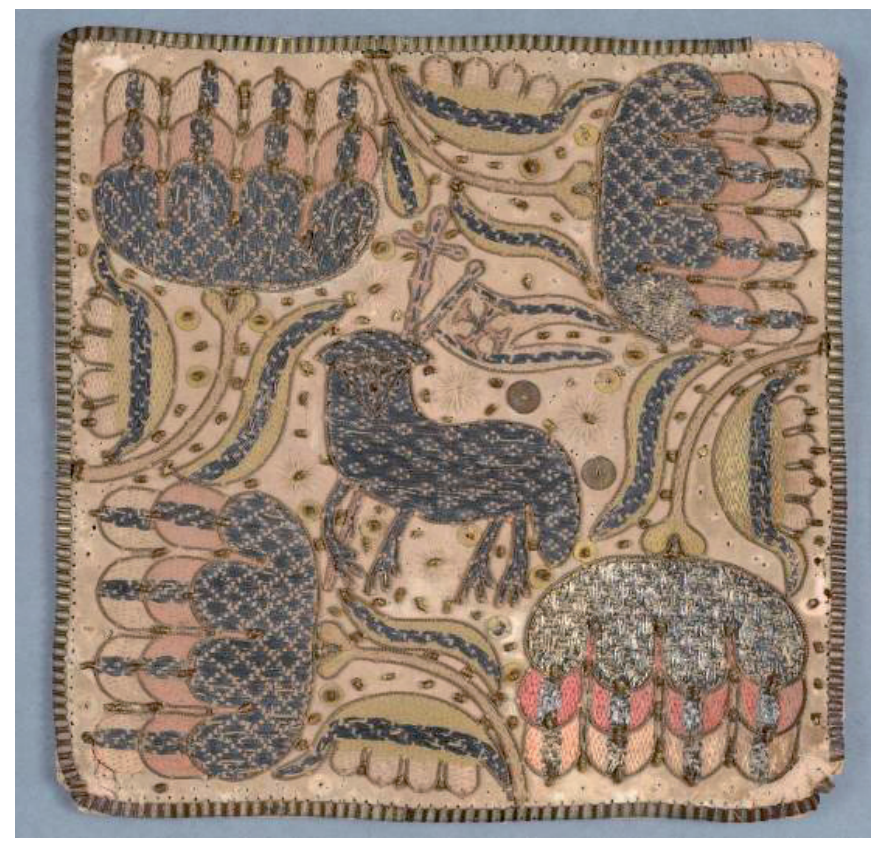

Slika 10. Pala inv.br. GMV KPO 1345, 19. st., stanje nakon radova, (fototeka HRZ-a, snimio Jovan Kliska)

Kazula inv.br. GMV 6587 rad je nepoznatog autora, a datirana je u 18/19. stoljeće. Izrađena je od svilenog atlasa broširanog raznobojnim svilenim, metalnim i pamučnim nitima te od tri različite tkanine spojene u cjelinu ukrasnim trakama. Površina kazule ukrašena je uskim, okomitim spiralnim viticama, u središnjem je dijelu izvezena ljubičastom pređom te iz nje izlaze listovi akanta, a u bočnim je dijelovima vitica izvezena zlatnom pređom u obliku lisnatih girlandi. Na bočnom su dijelu izvezeni po jedan ljubičasti, odn. crveni božur dok su u središnjem dijelu izvezene ruže i potočnice.

Posebnost ove tkanine jest središnja tkanina prednje i stražnje strane koje su u mnogočemu slične, ali nisu identične; uz primjenu pređa različitih boja različita je i upotreba veza; na prednjoj središnjoj tkanini tkano je ukrasnom pređom koja je tipična za 18. stoljeće, tzv. chenille pređa s nitima u obliku „dlakave gusjenice“. Na prednjoj i stražnjoj središnjoj tkanini nalazi se još jedna pređa 
BRANKA REGOVIĆ, MARIJA ZUPČIĆ, MARTA BUDICIN: Tekstilni predmeti iz Gradskog muzeja Varaždin ...

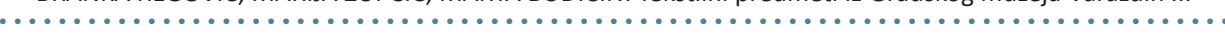

često korištena u 18. stoljeću, a to je tzv. frost ili frise pređa gdje su svilene niti presavijene tako da tvore čvoriće oko kojih je omotana metalna lamela. Smatra se da su ove tkanine tzv. „uzornice tkanja“ gdje je tkalac isprobavao različite boje i pređe na istom motivu sve do konačnog rezultata kojim bi bio zadovoljan. Takve skupocjene tkanine poklanjale su se crkvama od kojih se potom izrađivalo liturgijsko ruho.

Osim nedostatka podstavne i međupodstavne tkanine, sama tkanina je zatečena izrazito oštećena, mjestimice u pramenovima zbog velikog gubitka osnove koja je bila preslaba za metalne i efektne niti. Zatečeno stanje kazule je dokumentirano, a provedene su laboratorijske i strukturne analize. Uslijedilo je suho čišćenje, vlaženje i ravnanje. Oštećenja su zatvorena podlaganjem novom tkaninom i šivanjem, a izrađena je i našivena nova podstava.

Kazula inv. br. GMV KPO 8222 izrađena je u drugoj polovici 19. stoljeća, a rad je nepoznatog autora. Izrađena je od svilenog damasta s vezom i metalnim nitima te pamučnom podstavom. Damast prednjih bočnih dijelova ukrašen je većim motivima sa zrcalno postavljenim parovima heraldičkih životinja te vrpcom s natpisima. Ovaj je motiv preuzet $s$ lukeških tkanina $s$ arapskim natpisima iz 14. stoljeća koja se čuva u Gdanjsku, s tom razlikom da su arapski natpisi ovdje zamijenjeni rečenicama iz Starog zavjeta, dok se motivi lavova, ptica i drveta života ponavljaju. ${ }^{3}$ Središnja prednja i stražnja strana kazule ukrašena je izvezenim četverolisnim medaljonima s crvenim plošnim cvjetovima. Na poleđini se u leđnom križu također nalaze izvezeni četverolisni medaljoni s vegetabilno-arabesknom dekoracijom, a u središtu križa izvezen je oveći medaljon s kristovim monogramom i viticama.

Stražnji bočni dijelovi su izrađeni od bijele damastne tkanine sa sitnijim uzorkom, odn. medaljonima s prikazima četiri evanđelista, a između njih nalaze se biljni motivi i četverolist.

Na kazuli su izvedeni samo nužni radovi potrebni za izlaganje na navedenoj izložbi.

Muzejskoj zbirci pripada i kazula inv. br. GMV KPO 1320 iz 17./18. stoljeća, rad nepoznatog autora. U muzej je pristigla kao dar župe u Klenovniku. ${ }^{4}$ Izrađena je od svijetloplavog i bijelog svilenog damasta u atlas tkanju, vjerojatno francuske provenijencije, a ukrašena je s dvije vrste metalnih čipki i vezom tzv. punto ungaro u središnjem prednjem dijelu.

\footnotetext{
3 Ariana MESEK, „O liturgijskom ruhu u fundusu Gradskog muzeja Varaždin“, Hrvatska akademija znanosti i umjetnosti Zavod za znanstveni rad u Varaždinu, Radovi Zavoda za znanstveni rad Varaždin, 23, Zagreb-Varaždin, 2012., 440.

4 Ariana MESEK Isto, 416.
} 
Svileni damast moguće je datirati u 17. stoljeće i to u desetljeće od 1660. do 1670. godine. ${ }^{5}$ Oba se uzorka sastoje od raznolikog manjeg i većeg cvijeća i lišća među kojima se raspoznaju narcisi, tulipani, stilizirani akant i pupoljci te karakteristične točkice i tanke, uvijene vitice. Po središnjem, prednjem dijelu kazule vertikalno je apliciran izvezeni dio, vjerojatno talijanske provenijencije datiran u 18. stoljeće. Radi se o raznobojnom vezu na platnu s motivom obrnutog slova "S", specifičnom po tome što je izvezen. Radi se o tzv. punto ungaro kojega ka-

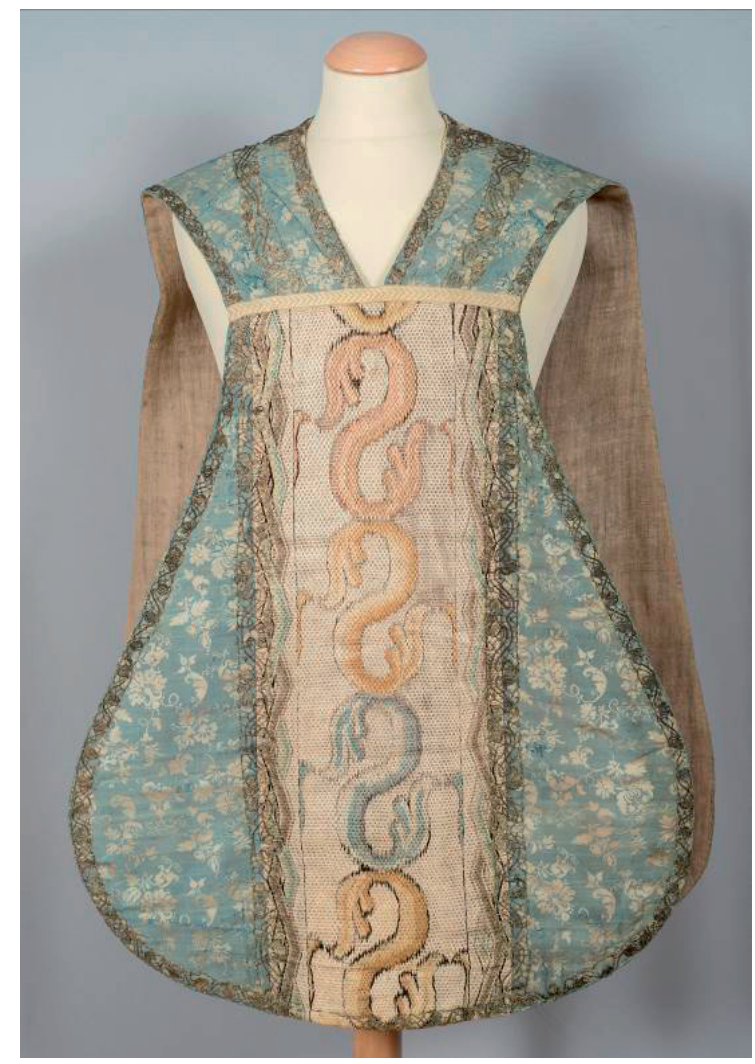

Slika 11. Kazula inv.br. GMV KPO 1320, 17./18. st., stanje nakon radova,

(fototeka HRZ-a, snimio Jovan Kliska)

Barbara MARKOWSKY, Europäische Seidengewebe des 13.-18. Jahrhunderts, Kunstgewerbemuseum der Stadt Köln, Köln, 1976., 266.; uzorak je br. 410, a vodi se kao lizerirani atlas, francuske provenijencije (Tours?), oko 1660. - 1670. 
BRANKA REGOVIĆ, MARIJA ZUPČIĆ, MARTA BUDICIN: Tekstilni predmeti iz Gradskog muzeja Varaždin ...

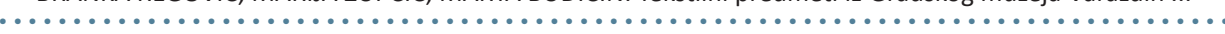

rakterizira okomito vezenje raznobojnim nitima. ${ }^{6}$ Već su u vrijeme kralja Luja XIV. u 17. stoljeću ovim vezom poznate manufakture u Gobelinu u Parizu, Aubussinu u središnjoj Francuskoj te u Beauvaisu u sjevernoj Francuskoj, ali i Italiji, ukrašavale tkanine kojima je prekrivan namještaj, a popularnost ovog veza seže do u 19. stoljeće.

Uz glavnu tkaninu i vez ova je kazula ukrašena i dvjema vrstama metalnih čipki koje su različite širine, ali istog tipa. Sastoje se od rjeđe strukture metalnih niti koje oblikuju valovitu mrežu sa stiliziranim polukružnim cvijetom u središtu svakog „vala“. Obje čipke imaju karakteristične ravne rubove, mogu se datirati u 17. stoljeće i vjerojatno su talijanske provenijencije.

Kazula inv. br. GMV KPO 1420 i stola inv. br. GMV KPO 1421 dio su istog liturgijskog kompleta datiranog u razdoblje od druge polovice 15 . do 18 . stoljeća, a izrađene su od ružičastog tafta te žutosmeđeg i crvenog baršuna s dvjema vrstama metalnih čipki. Kazula dolazi iz varaždinske kapelice sv. Lovre, a pripadala je sakralnom inventaru grofova Erdödy. Sastavljena je od različitih dijelova među kojima se ističe rijetki i dragocjeni umetak apliciran na stražnjem dijelu od crvenog svilenog baršuna sa žutom podlogom koji je rezan u dvije visine, tzv. alto-basso, lizeriran svilenim žutim i pozlaćenim nitima u bouclé i allucciolato efektu i ukrašen motivom čkalja te vjerojatno nara unutar cvjetnog medaljona od crvenog baršuna.

Taj je umetak moguće datirati u drugu polovicu 15. stoljeća po uzoru na brojne baršune istoga tipa koji su izrađivani tijekom 15. i 16. stoljeća u Veneciji i Firenci. ${ }^{7}$

Uz ovaj rijetki i dragocjeni primjerak baršuna, kazula je dodatno ukrašena metalnim čipkama dviju različitih širina, od kojih se na rubnom dijelu kazule nalazi uža čipka, a po središnjem dijelu i oko vratnog izreza šira. Ove čipke su tipološki bliske đenoveškim čipkama iz 17. stoljeća, a karakterizira ih izrazita gustoća niti te kompleksne kompozicije vijugavih i ravnih niti unutar kojih se pojavljuju stilizirani cvjetovi. Tanja se čipka istog tipa ponavlja po rubovima kazule, a sastoji se od plosnatih manjih, polukružnih cvjetova papirusa.

6 La Collezione Gandini Tessuti dal XVII al XIX secolo, ur. Donata Devoti i Marta Cuoghi Costantini, Musei Civici di Modena, Franco Cosimo Panini Editore, Modena, 1993., 191-195.

7 Doretta DAVANZO POLI, Le collezioni della Fondazione di Venezia. I tessili Fortuny di Oriente e Occidente, Fondazione di Venezia, 2008., 221-239. 


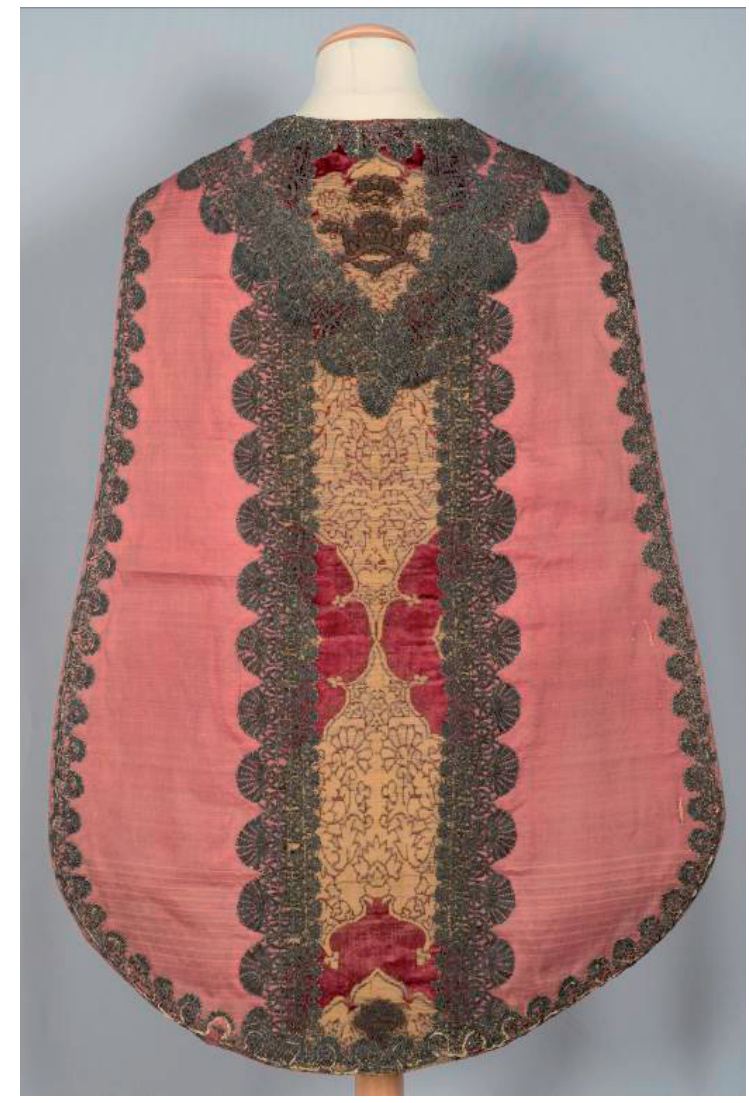

Slika 12. Kazula inv. br. GMV KPO 1420, 15.-18. st., stanje nakon radova, (fototeka HRZ-a, snimio Jovan Kliska)

Stola je izrađena od ružičastog tafta, žutosmeđeg baršuna te dvije različite čipke od metalnih niti. Rad je nepoznatog autora, a datirana u 17. i 18. stoljeće. Ispod sadašnjeg tafta i baršuna tijekom konzervatorsko-restauratorskih radova utvrđena je prisutnost plavog tafta što pokazuje kako je na ovaj predmet naknadno aplicirana glavna tkanina u želji da se tako kompletira s kazulom. Metalne čipke su također aplicirane kasnije i dvojake su; imamo starije, patinirane koje tvore gusto pleteni križ na središnjem i donjim krajevima te noviju čipku koja obrubljuje rubove predmeta.

Osim izrađene dokumentacije zatečenog stanja i oštećenja te različitih analiza vlakana i tkanina izvedeni su cjeloviti konzervatorsko-restauratorski radovi. 
Kazula inv. br. GMV KPO 1418 i stola inv. br. GMV KPO 1419 pripadaju istom kompletu liturgijskog ruha iz druge polovice 18. stoljeća. Kazula je izrađena od dvije različite glavne tkanine; središnje svilene beige tkanine broširane raznobojnim svilenim nitima koje tvore sitne cvjetne buketiće i čipkaste uvijene trakice raspoređene vertikalno po tkanini te bočne svilene višebojne droguet tkanine geometriziranih i stiliziranih biljnih motiva.

Motivi sa središnjeg dijela kazule karakteristični su za razdoblje od 1755. do 1765 . godine ${ }^{8}$, a biljni motivi i trolisti na izlomljenoj cik-cak podlozi droguet tkanine tvore raport manjih dimenzija karakterističan za ovu vrstu svilene tkanine iz treće četvrtine 18. stoljeća koja je bila jedan od najznačajnijih proizvoda švedskih i nizozemskih tekstilnih manufaktura. Kazula ima lanenu podstavu i lanenu međupodstavu koja je oslikana temperom cvjetnim motivima i viticama. Dodatno je ukrašena s tri vrste metalnih čipki iz 18 . st. izrađenih ručno na batiće.

Stola inv. br. GMV KPO 1419 se sastoji od iste svilene droguet tkanine stiliziranog i geometriziranog biljnog motiva te lanene podstave, a ukrašena je i metalnom čipkom. Između svilene i lanene tkanine nalazi se lanena međupodstava. Navedeni su predmeti zatečeni u lošem stanju očuvanosti, posebno je to bilo izraženo kod oslikane međupodstave kazule.

Konzervatorsko-restauratorski radovi su bili opsežni i zahtjevni. Za kazulu je izrađena nova međupodstava, dok je oslikana međupodstava odvojena i pohranjena u zasebnu beskiselinsku kutiju.

8 Barbara MARKOWSKY, n. dj., 333.; kat. br. 589 (sličan motiv). 
Radovi Zavoda za znanstveni rad HAZU Varaždin; br. 30, 2019, str. 283-309

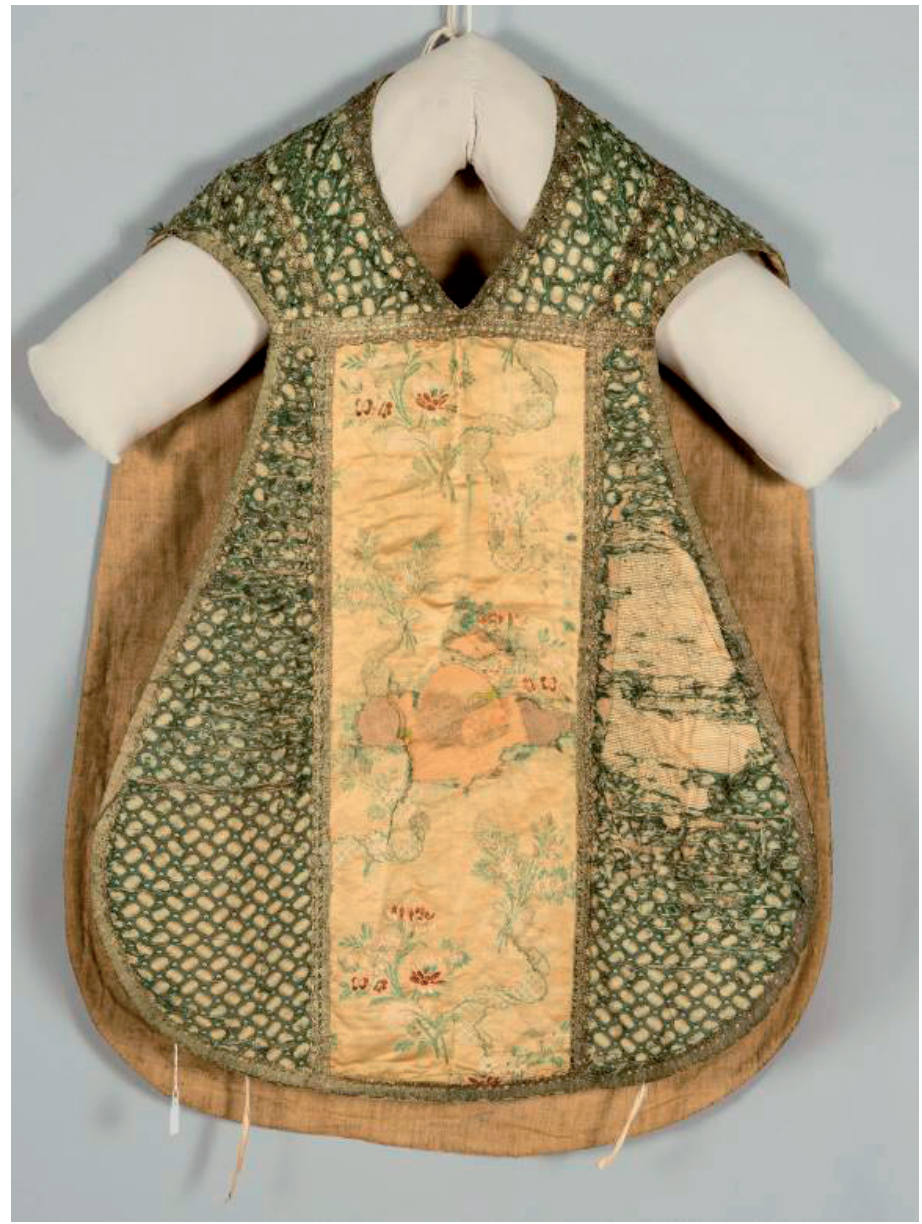

Slika 13. Kazula GMV KPO 1418, druga polovica 18. st., stanje prije radova, (fototeka HRZ-a, snimio Jovan Kliska) 


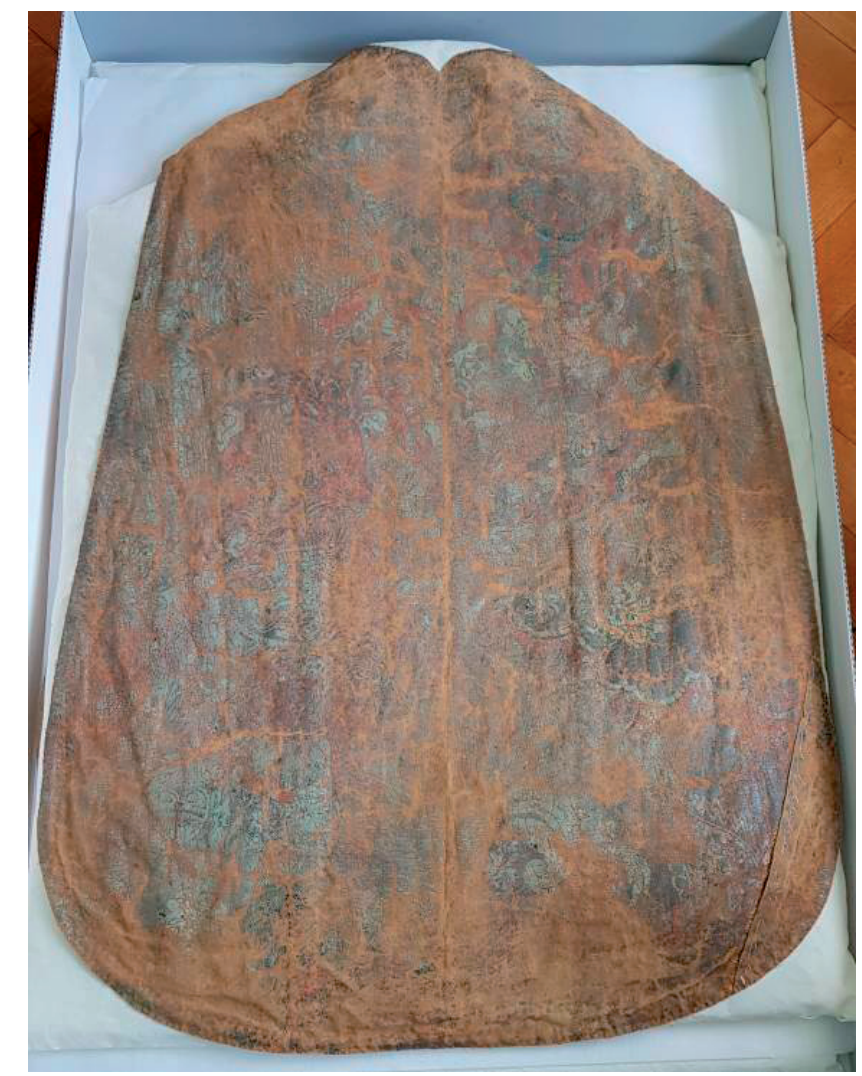

Slika 14. Oslikana međupodstava kazule GMV KPO 1418, 18. st., zatečeno stanje, (fototeka HRZ-a, snimio Jovan Kliska)

Cjeloviti konzervatorsko-restauratorski radovi izvedeni su i na grafici na svili inv. br. GMV KPO 1317 i zastavi općine Vinica. Predmeti su restaurirani 2014. godine za izložbu Varaždin pod habsburškom krunom u Gradskom muzeju Varaždin, održanu 2015. godine.

Grafika na svili s prikazom Kristovog uskrsnuća je bakropis izveden na žutom svilenom atlasu 1745. godine, a rad je nepoznatog autora. Dolazi iz Budima u Mađarskoj, a posvećena je Kaločkom nadbiskupu i prvom županu virovitičke županije Ljudevitu Patačiću od Zajezde te prethodno u vlasništvu varaždinskih isusovaca. Predložak za ovaj bakropis nadovezuje se na P.P. Rubensa; analogije su vidljive u oblikovanju figure Krista, oblacima, draperiji i mišićavim ljudskim figurama koje sudjeluju u prizoru. 
U donjem dijelu grafike je prikaz triju kanonskih tablica s tekstom na latinskom jeziku gdje se spominje i ime naručitelja s godinom 1745. ispisanom rimskim brojevima. Iznad prikaza Uskrsnuća nalazi se natpis „DE MANV MORTIS LIBERABO EOS, DE MORTE REDIMAM EOS“ iz Starozavjetne knjige proroka Hošee. Konzervatorsko-restauratorski radovi na ovoj su umjetnini bili izrazito složeni. Diploma je uklonjena s neprimjerene deformirane drvene podloge koja je uzrokovala velika oštećenja. Nakon svih potrebnih radova postavljena je na novu podlogu te tako pripremljena za pohranu i izlaganje.

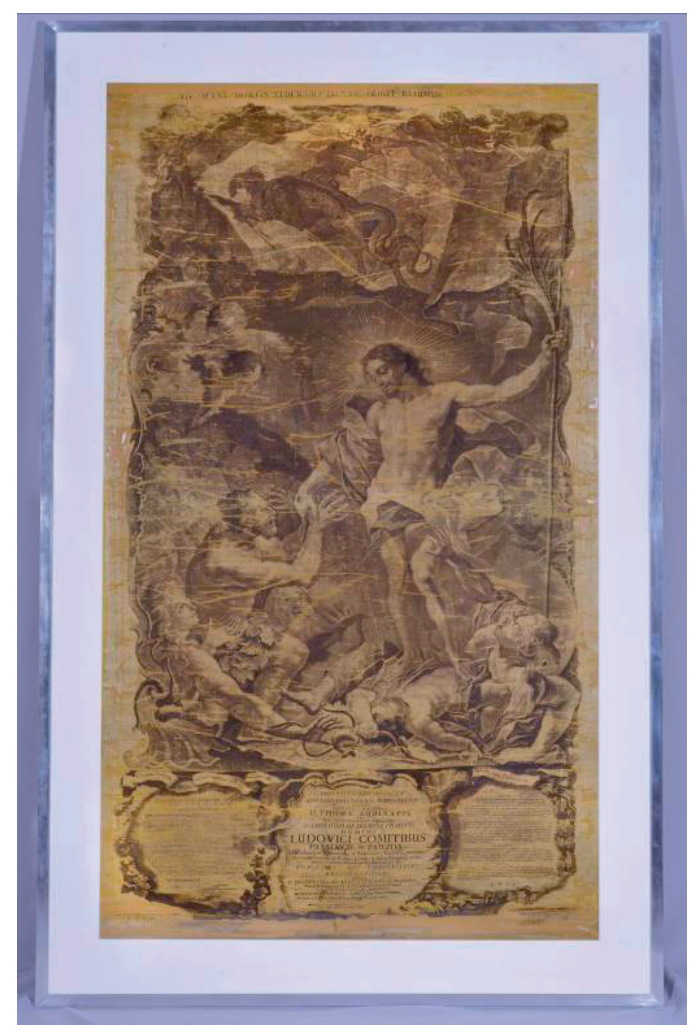

Slika 15. Grafika na svili GMV KPO 1317, 1745. g., stanje nakon radova, (fototeka HRZ-a, snimila Nikolina Oštarijaš)

Zastava općine Vinica inv. br. GMV KPO 1408 izrađena je 1833. godine, a rad je nepoznatog autora. Sastoji se od dvobojnog, bordo svilenog i žutosmeđeg vunenog damasta, a ukrašena dvostranom slikom u tehnici ulja na platnu. Dodatno ima dvobojni, crvenoplavi, drveni stijeg i metalne dijelove. 
U središnjem je dijelu zastave smještena dvostrana ovalna slika s portretom kraljice Marije Terezije s dva manja ovala u donjem dijelu prednje strane. U manjim su ovalima portreti njezinih sinova Josipa II i Leopolda. Sa stražnje strane nalazi se prikaz Bogorodice s Djetetom. Ovalni je medaljon s portretima uokviren lovorovim vijencem s rozetom u vrhu.

Iznad portreta Marije Terezije, na tkanini zastave nalazi se pozlaćeni natpis "VEXILLUM OPIDI VINICENSIS", odn. „Zastava općine Vinica“. Ispod tog natpisa je ispisana godina 1833. i natpis „MARIA THERESIA REGINA“. Na stražnjoj strani zastave iznad ovalne slike na tkanini je ispisan natpis „SANTA MARIA ORA PRO NOBIS“. Na rubnim dijelovima zastave prišivena je prugasta ukrasna traka sa svilenim dvobojnim resicama Zastava je pričvršćena metalnim čavlima ovalnih kapica za drveni stijeg, a na vrhu stijega nalazi se metalni dio kojem nedostaje završetak (koplje, kugla i sl.).

Konzervatorsko-restauratorski radovi su bili opsežni i zahtjevni, a izvedeni su u suradnji s Odjelom za štafelajno slikarstvo te Odsjekom III za drvenu polikromiranu skulpturu i namještaj.

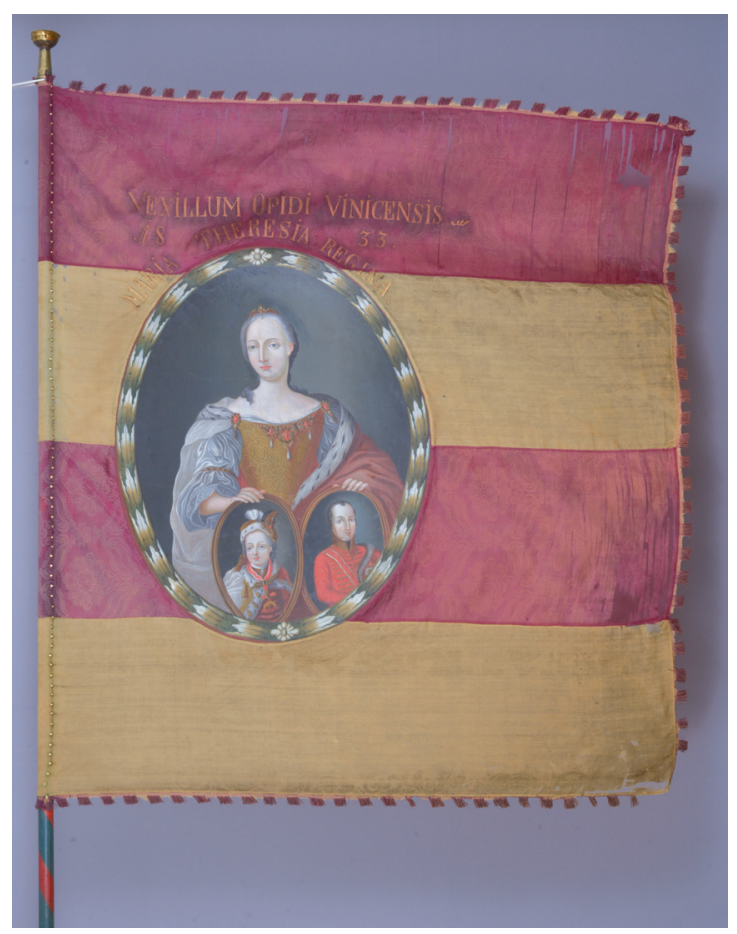

Slika 16. Zastava općine Vinica inv. br. GMV KPO 1408, 1833. g., stanje nakon radova, (fototeka HRZ-a, snimila Nikolina Oštarijaš) 


\section{ZAKLUUČAK}

Suradnja između Gradskog muzeja Varaždin i Hrvatskog restauratorskog zavoda započeta 2007. godine rezultirala je obnovom sveukupno trinaest odjevnih predmeta i modnih dodataka datiranih u razdoblje od druge polovice 18. stoljeća do 1905. godine, obuhvativši stilska razdoblja od kasnog baroka do edvardijanskog doba. Navedeni su predmeti raznorodni po tipu; od lepeza i suncobrana preko kapa za žalovanje do haljina, ogrtača, kaputića i bluza koji su danas dio Stalnog postava muzeološke cjeline Kultura odijevanja od 18. do sredine 20. stoljeća Gradskog muzeja Varaždin.

Od liturgijskih predmeta i opreme restaurirane su četiri kazule, dvije stole i jedna pala, datirani od druge polovice 15. stoljeća do druge polovice 19. stoljeća. Predmeti su izloženi na izložbi Vjera Ufanje ljubav u 2013. godini. Uz to, povodom izložbe Varaždin pod habsburškom krunom u 2015. restaurirana je jedna grafika na svili iz 1745. godine te zastava općine Vinica iz 1833. godine. Navedeni su predmeti namijenjeni budućoj Sakralnoj zbirci muzeja.

Konzervatorsko-restauratorski radovi ovim predmetima, svojom raznorodnošću materijala i složenim izvedbenim tehnikama predstavljali su pravi izazov s konzervatorsko-restauratorskog aspekta, s tim da su u okviru konzervatorskorestauratorskih radova za većinu predmeta izrađene i izložbene lutke i stalci za izlaganje.

\section{LITERATURA}

1/ Janet ARNOLD, Patterns of Fashion 2, Englishwomen's dresses and their construction c. 1860-1940, Macmillan, 1977., London.

2/ Doretta DAVANZO POLI, Le collezioni della Fondazione di Venezia. I tessili Fortuny di Oriente e Occidente, Fondazione di Venezia, 2008.

3/ Lara FLECKER, A Practical Guide to Costume Mounting, Elsevier, ButterworthHeinemann, Oxford, 2007.

4/ Barbara MARKOWSKY, Europäische Seidengewebe des 13.-18. Jahrhunderts, Kunstgewerbemuseum der Stadt Köln, Köln, 1976.

5/ Ariana MESEK, „O liturgijskom ruhu u fundusu Gradskog muzeja Varaždin“, Hrvatska akademija znanosti i umjetnosti, Radovi Zavoda za znanstveni rad Varaždin, 23/2012.

6/ La Collezione Gandini Tessuti dal XVII al XIX secolo, ur. Donata Devoti i Marta Cuoghi Costantini, Musei Civici di Modena, Franco Cosimo Panini Editore, Modena, 1993. 


\section{SAŽETAK}

\section{TEKSTILNI PREDMETI IZ GRADSKOG MUZEJA VARAŽDIN \\ RESTAURIRANI NA ODJELU ZA TEKSTIL, PAPIR I KOŽU HRVATSKOG RESTAURATORSKOG ZAVODA}

Stalni postav Kulturnopovijesnog odjela Gradskog muzeja Varaždin u 2014. je godini obogaćen vrijednom muzeološkom cjelinom Kultura odijevanja od 18. do sredine 20. stoljeća za čiju je realizaciju zaslužna i višegodišnja uspješna suradnja Odjela za tekstil, papir i kožu Hrvatskog restauratorskog zavoda i Gradskog muzeja Varaždin. Restaurirani ženski odjevni predmeti i pripadajući modni dodaci potječu iz različitih stilskih razdoblja od kasnog baroka do edvardijanskog doba, a krasi in izrazita raznorodnost materijala i tehnika izrade.

Za potrebe izložbe Vjera, ufanje, ljubav u 2013. godini te budući stalni postav Sakralne zbirke restaurirano je liturgijsko ruho datirano od druge polovice 15. do druge polovice 19. stoljeća, a za potrebe izložbe Varaždin pod habsburškom krunom u 2015. godini restaurirane su grafika na svili iz 1745. godine i zastava općine Vinica iz 1833. godine.

Ključne riječi: Gradski muzej Varaždin; Muzeološka cjelina Kultura odijevanja od 18. do sredine 20. stoljeća; ženski odjevni predmeti i modni dodaci od druge polovice 18. do početka 20. stoljeća; liturgijsko ruho i oprema od druge polovice 15. do druge polovice 19. stoljeća; konzervatorsko-restauratorski radovi uz doradu izložbene lutke. 


\section{SUMMARY \\ TEXTILE OBJECTS FROM THE VARAŽDIN CITY MUSEUM RESTORED AT THE DEPARTMENT FOR TEXTILES, PAPER AND LEATHER OF THE CROATIAN CONSERVATION INSTITUTE}

In 2014, due to the longstanding successful cooperation between the Department for Textiles, Paper and Leather of the Croatian Conservation Institute and Varaždin City Museum, Permanent museum exhibition of the Culture and History Department of the Varaždin City Museum was expanded and enriched with an exceptionally valuable museum collection Culture of Clothing. Restored objects, women's clothing and related fashion accessories, belong to different style periods, from late Baroque to the Edwardian period, and are characterized by a large variety of materials and techniques.

Simple liturgical vestments dated from the 15th century to the second half of the 19th century were restored for the Faith, Hope, Love exhibition, held in 2013, and the future permanent exhibition of the Sacral Collection. Graphics on silk from 1745 and the Flag of Vinica Municipality from 1833 were restored for the Varaždin under the Habsburg crown exhibition held in 2015.

Key Words: Varaždin City Museum, Culture of Clothing museum collection; women's clothing and related fashion accessories from the second half of the 18 th century to the beginning of the 20th century; liturgical vestments from the 15 th century to the second half of the 19th century; conservation and restoration with costume mounting. 
